$\xi=-1$

\title{
Development of Smart Kit Rainwater Harvesting System for Potable Water Purpose
}

\author{
N. M. Sunar ${ }^{1,2,3 *}$, A. T. Kosat ${ }^{1}$, H. Harun ${ }^{1,3}$, N. H. A. Hamid ${ }^{1,3}$, A. Khalid ${ }^{1,3}$, E. Zaidi ${ }^{2}$, A. T. S. Azhar ${ }^{2}$ \\ ${ }^{1}$ Faculty of Engineering Technology (FTK), Universiti Tun Hussein Onn Malaysia, Pagoh Higher Education Hub, KM 1, Jalan Panchor, \\ 84600 Pagoh, Johor, MALAYSIA. \\ ${ }^{2}$ Research Centre for Soft Soil (RECESS), Universiti Tun Hussein Onn, 86400, Parit Raja, Batu Pahat, Johor, MALAYSIA. \\ ${ }^{3}$ Advanced Technology Centre (ATC), Faculty of Engineering Technology, Universiti Tun Hussein Onn Malaysia, Pagoh Higher Educa- \\ tion Hub, KM 1, Jalan Panchor, 84600 Pagoh, Johor, MALAYSIA. \\ *Corresponding author E-mail: shuhaila@uthm.edu.my
}

\begin{abstract}
The Smart Kit Rainwater Harvesting (RWH) system has the potential to contribute to the conservation of clean water usage. The aim of this study is to build an affordable rainwater storage system for all type houses with easy installation and friendly user. The current constraints on the installation of rainwater storage system in the market requires a fairly expensive cost, and skilled technical workers to install it. In contrast, the Smart Kit RWH, is friendly built in a complete set that is easy to install and easy to maintain by homeowners. This system is very suitable for the use in agriculture and farming. This Smart Kit RWH consist of water storage tank, existing gutter and main pipe, first flush diverter and some connector pipe to create this complete system. This product is limited to storing untreated rain water quality, and the quality of rainwater collected can be used as water storage for household and sanitary equipment such as flushing cistern and other potable water usage. Nevertheless, this contributes to the good and the benefits of individuals, communities and nations. This product able to help the rural population in particular of having problems in getting clean water. Hopefully, with the production of this system, it can foster the public's awareness of the advantages and benefits of installing rainwater storage systems at home, plantation and farming.
\end{abstract}

Keywords: Rainwater harvesting system; rainwater storage system; Smart Kit RWH.

\section{Introduction}

\subsection{Background of study}

In this century, the world has realized the re-use of rainwater for home, landscaping and agriculture is very needed. Before the system was expanded, rainwater had already been collected or captured through the roof of the house and stored in reservoirs. Rainwater is a free source of water that has a near-pure quality of water. It can be used to supply drinking water as well as non-drinks. For drinks, this rainwater needs to be treated to remove or kill the bacteria contained therein. Rainwater harvesting is the process of collecting, storing, and later reusing rainwater from surfaces such as roofs [1]. The rainwater collection and reuse system or also known as the rain water harvesting system are one of the Best Management Practice in effective water management. The system aims to delay surface runoff flow and promote efficient use of water. Nowadays, most regions around the world have adopted rainwater harvesting to mitigate the effects of floods due to climate change. The rainwater harvesting system was introduced after the 1998 drought by Ministry of Housing and Local Government [2]. The initial initiative of RWHS implementation in Malaysia began in 1998 following the water crisis in Kuala Lumpur. The impact of this water crisis has brought awareness to the Malaysian government to find solutions on how to deal with and mitigate the crisis of the absence of clean water resources. In that case, an effort has been made in Malaysia where the installation of a rainwater collection system was issued by the Ministry of Housing and Local Government which aims to encourage the public to be more sensitive and know about the installation of rainwater collection systems [3-4]. In an effort to intensify the implementation of the installation of rainwater storage systems, by looking at and studying research sources for researchers, the cheap and easyto-install rainwater harvesting systems will be built to ensure that all societies are able to have a clean water storage system from rainwater. In addition to helping make a positive impact on the environment, there are also many advantages to using this rainwater harvesting system. Among them is, there is no cost to use rain water except for initial costs for system installation [4-5]. With the creation of a cheap and easy-to-install rainwater harvesting system, it directly contributes to the huge savings of water users in Malaysia, as well as controlling the use of clean water that is often in high demand in Malaysia. The government is also able to make the country as the focus of the world because of its success successful installation of rain water harvesting system for all levels of society. Therefore, the aim of this study to build facilitate people to install affordable rainwater storage systems. As we know current constraints installing a rainwater storage system in the market requires a fairly expensive cost, and skilled of technical workers to install it. This Smart Kit RWH is consist of water storage tank, existing gutter and main pipe, first flush diverter and some connector pipe to create this complete system. 


\subsection{Rainwater Harvesting at Malaysia}

The rainwater harvesting system was introduced after the 1998 drought by Ministry of Housing and Local Government (MHLG). The 1999 'Guidelines for Installing a Rainwater Collection and Utilization System' can be seen as the initial phase of the rainwater harvesting policy in Malaysia. The main purpose of these guidelines is to reduce the dependence on treating water and provides a convenient buffer in times of emergency or a shortfall in the water supply. It also proposed the construction of 'mini dams' or rainwater tanks in urban area instead of continuing to build giant dams upstream [4-5]. These guidelines are intended as an 'ideal manual' for reference for those who want to install a rainwater harvesting and utilization system [5]. After five years of this guideline, namely in 2004, the Ministry of Housing and Local Government has prepared another cabinet paper to the National Water Resources Council to encourage government buildings to install a rainwater collection and utilization system. The Council later announced that rainwater utilization is to be encouraged, but not mandatory. The Department of Irrigation and Drainage and The Ministry of Energy, Water and Communication (KTAK) are the two government agencies that implement the rainwater harvesting system in the early.

\section{Materials and Methods}

\subsection{Materials selection}

The first step is the material selection which involved water tanks, first flush diverter, UPVC pipe and, existing gutter and down pipe (refer to Table 1). This material selection is very important as it involves the cost of producing and maintaining the RWHS system. Next step is the system design the RWHS system. The design of this system is more focused on the design of the water tank and first flush diverter that distinguish the existing water tank with the water tank RWHS in its size and appearance for easy wall installation. The last stage of this development is the construction process. The installation of the RHWS was done in the security building in Pagoh UTHM residential college. The product development is analysed on the completion of the fully assembled system.

Table 1 Designing and material choosing RHWS component

\begin{tabular}{|l|l|l|}
\hline \multicolumn{1}{|c|}{ Method } & \multicolumn{1}{|c|}{ Detail } & \multicolumn{1}{c|}{ Reference } \\
\hline $\begin{array}{l}\text { Gutter and } \\
\text { Sownpipe }\end{array}$ & $\begin{array}{l}\text { Design: Rectangular } \\
\text { gutter shape } \\
\text { Material: UPVC Pipe }\end{array}$ & $\begin{array}{l}\text { NAHRIM Technical Guide } \\
\text { No.2: The Design Guide For } \\
\text { Rainwater Harvesting Sys- } \\
\text { tem [3] }\end{array}$ \\
\hline Tank & $\begin{array}{l}\text { Design capacity: 60 } \\
\text { gallons } \\
\text { Material: Poly-Tank }\end{array}$ & $\begin{array}{l}\text { The Gulf Islands Rainwater } \\
\text { Connection Ltd [6] }\end{array}$ \\
\hline $\begin{array}{l}\text { First Flush } \\
\text { Diverter }\end{array}$ & $\begin{array}{l}\text { Design capacity: 8 liter } \\
\text { Material: UPVC pipe }\end{array}$ & Rain Harvesting Pty Ltd [7] \\
\hline
\end{tabular}

\subsection{Size of water storage tank}

Determination of water tank capacity is very important. In this project, the formula from Gulf Island Rainwater Connection in 2015 was used to calculate the size of the water storage. Referring to the method, it was stated that 1 inch of rain falling on 1 square foot of surface $=0.52$ gallons of water. In the determination of the size of water tank, the monthly precipitation is needed to be recorded as mentioned in a Figure 1 Weather April in Muar, Malaysia 2018, stated that the rainfall was 7.8 inches. The catchment surface of the security cottage building in the study was also recorded 438 square feet for the calculation. After getting the value of monthly rainfall, area of the rooftop, then the process of calculating the water tank size can be determined.

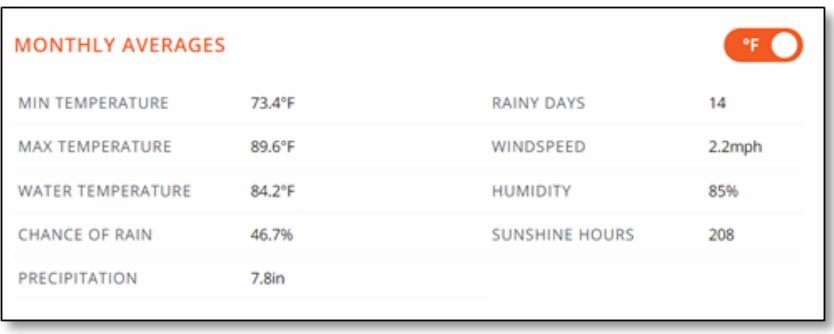

Fig. 1: Weather April in Muar, Malaysia [8]

1 Inch of Rain Falling On 1 Square Foot of Surface $=0.52$ gallons

Therefore,

(7.8-inch $\mathrm{x} 438$ square foot) $\mathrm{x} 0.52=1776.528$ gallons

To account for the appropriate runoff coefficient below include it in the equation (we used 95\%):

So that,

$(7.8 \times 438) \times 0.95 \times 0.52=1687.7$ gallons $\approx 1700$ gallons

One month of water collection is 1700 gallon $\approx 6435.2$ Litre

Assume, one day of water collection

$1700 / 30$ days $=56.6$ gallon

$\approx 60$ gallon @ 230 liter

The best size of water tank is 60 gallons.

\subsection{First flush volume estimation}

A rainwater first flush diverter functioned to prevent the first few litres of rainwater from entering water tank. It was also known as a roof washer, simple contraption that diverts the first flow of water away from a rainwater catchment system [8-10]. The first pass of water in any storm essentially washes roof of all the sediments that have collected since the last rain. The idea was to divert the first flush that could ensure cleaner water in rainwater storage tank [11-16]. According to Australian Company Rain Harvesting Pty Ltd, it is important to prevent heavy sediments and other roof pollutants from entering the rainwater tank [7]. The amount of water diverted should be a minimum of $20 \mathrm{~L}$ per 100 square meters of roof area (or $0.2 \mathrm{~L} \mathrm{per}^{2}$ ) [6].

Table 2: Rain Harvesting Pty Ltd, product catalogue [6]
Pollution Factor For The Roof

Minimal Pollution - divert $0.2 \mathrm{~L}$ per $\mathrm{m}^{2}$

Open field, no trees, no bird dropping, clean environment

Substantial Pollution - divert $2 \mathrm{~L}$ per $\mathrm{m}^{2}$

Leaves and debris, bird droppings, various animal matter, e.g. dead insects, skins etc.

Roof area, $5.28 \times 7.70=40.656 \mathrm{~m}^{2} @ 438$ square feet. Since the building was open field, thus there were no trees, no bird dropping and clean environment, thus the pollution factor for the roof area is $0.2 \mathrm{~L}$ per $\mathrm{m}^{2}$. The equation to calculate first flush diverter as follow [6]

Roof Area X Pollution Factor $=$ Liters to be diverted.

$\begin{aligned} & \text { Diversion Factor For A First Flush } \\ & \text { Water Diverter }\end{aligned}$
$\mathrm{m}^{2}$ Roof Area X Pollution Factor
$=$ Liters to be diverted.
Example for a minimal polluted
roof of $100 \mathrm{~m}^{2}$
$100 \times 0.2=20$ Liters to be divert-
ed.
Example for a heavily polluted
roof of $100 \mathrm{~m}^{2}$
$100 \times 2=200$ liters to be diverted
roof of $100 \mathrm{~m}^{2}$ $100 \times 2=200$ liters to be diverted 
The best size of first flush diverter is 8 Liters.

\section{Results and Discussion}

\subsection{Rainwater harvesting design and installation}

The Smart Kit RWH system design consists of three main components, first flush diverter, conveyance system and water storage. Each measure of pipe length and position of water tank depended on the design of the building. The concept of the design remains the same and unchangeable, where the position of storage water tank will be placed on the walls of the building using a selfbracket. The completed building will have a rain gutter and down pipe as provided. Therefore, the installation of this Smart Kit RWH only requires the installation of piping work and storage water tank as shown in Figure 2.

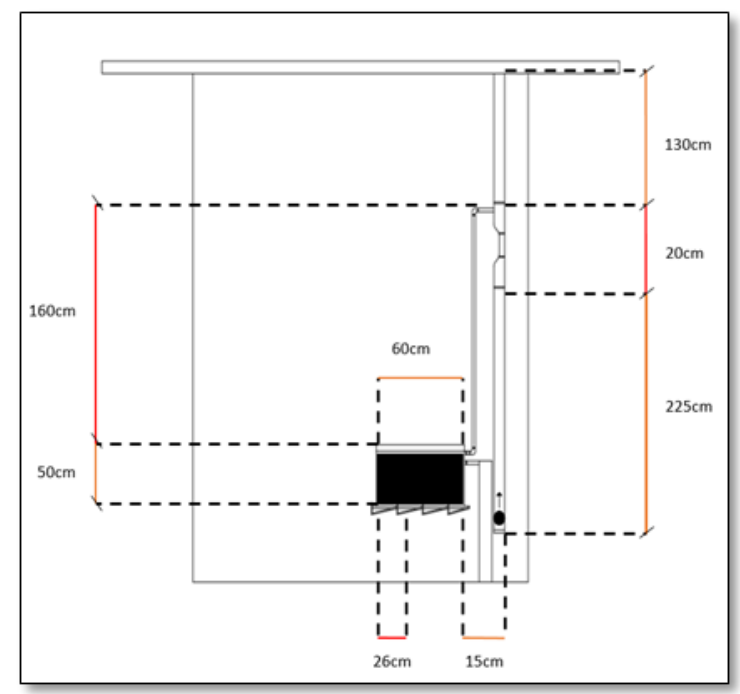

Fig. 2: Dimension Design of Smart Kit RWH System

The main component in this Smart Kit RWH system is the first flush diverter as shown in Figure 3. The first flush diverter function is to replace the rain water filter. The first flush pipe system stored dirty water, enabling clean water to be filtered into the tank. The first flush diverter system works by using a floating ball. When the pipeline fills the first flush pipe area. The float ball will cover the hole in the 2-inch pipe section. This will directly prevent dirty water from continuously entering the plumbing that flows into the storage tank. The water in the first flush tank can be discarded after the rain stops. A screw cap is attached to the bottom of the first flush pipe that can be open by manually. For the design of a water storage tank, the rectangular design perfectly suited to the space-saving and easy installation. Water tank capacity was limited to 60 gallons only. This was to maintain the stability of the suspended water tank on the walls of the building. The 60 gallon of water weight was equivalent to 230 kilograms. Its height was also restricted to not exceed one meter from the floor surface level. This is to protect the safety of users and people around the water tank. Moreover, in the water tank there were two inflow and outflow pipeline designed. The inflow pipe was separated from the main pipe out flow. The diameter of the drain pipe hole was 4 inches. It was also designed with a hole provided for the water tap to drain the water in the tank.

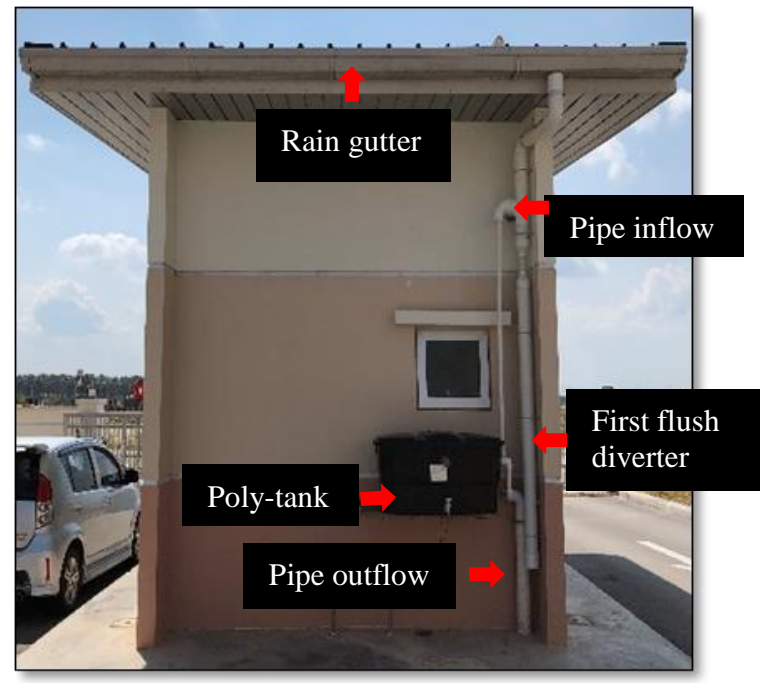

Fig. 3: Complete installation of Smart Kit RWH system

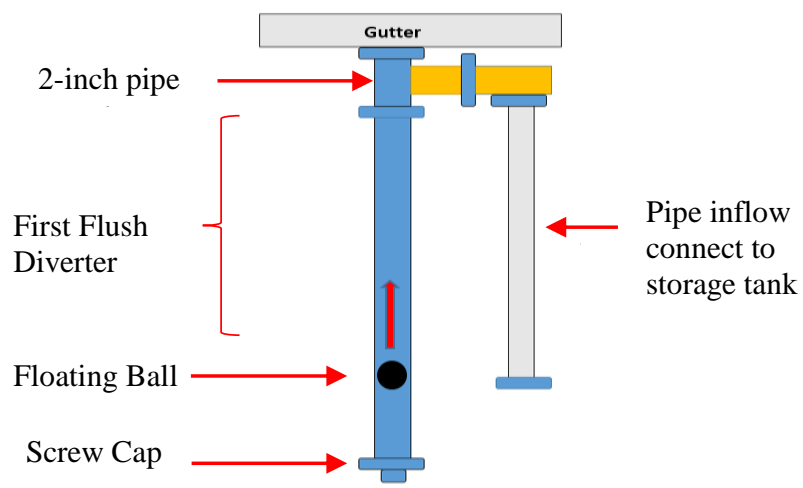

Fig. 4: Design of a first flush diverter

The Smart Kit RWH system was firstly mounted with the selfbracket on the walls of the building. One self-bracket unit was able to accommodate up to 60 kilograms of weight, thus four units of self-brackets were fitted with a 6 inch wall plug. Walls were laid to fit the wall plug. The distance between the self-brackets was $25 \mathrm{~cm}$. A wooden board was placed as a floor holder to place the tank. The board placed on the self-bracket were screwed by a 2 -inch nut to stabilize the board position. The designed water storage tank was put on top of the board to measure the length of pipe from rain gutters. Next, the existing UPVC pipe measured that $100 \mathrm{~mm}$ of the building was cut into pieces to make pipe connection work from the rain gutter to the main pipe (inflow). Two of $100 \mathrm{~mm}$ elbow fitting units also used for pipe jointing process. The main pipe (inflow) has a length of $130 \mathrm{~cm}$ which was connected first flush diverter. The volume and pipe length of first flush diverter was determined using formula (2). The roof area of the building was recorded 40.6 square feet wide and $225 \mathrm{~cm}$ length. This pipe of first flush diverter will be connected to a water tank. A hole in the water tank was created to install the vconnector in purpose of connecting pipe inflow and out-flow. By using a $48 \mathrm{~mm}$ diameter hole saw, the water tank portion is punched by drill. There were two holes acquired to install the vconnector fastener with seal tapes. Continuously, the remaining UPVC pipe was cut and placed at the bottom of the pipe first flush diverter for the screw cap installation. As the tank was positioned, pipe fittings were installed to connect the pipe to the water tank by using $90^{\circ}$ elbow. The 2 -inch pipe is used to discharge the inflow and outflow water in the tank. Moreover, the tap on the pipe connection was installed to avoid leakage. All pipe connections must be wrapped with pipe glue to avoid any leakage. The overall installation process of Smart Kit RWH only involved three main 
components consisted of conveyance system, first flush diverter and water storage tank which were easily assembled for domestic use.

\subsection{Observation quality of water collection}

This study involved the examination of the water quality collection. It was found that there was a difference between the water quality in the tank and the first flush diverter observed. This proves that the rainwater flowing for the first flow was polluted and needed to be removed from flowing into the water tank storage. The water quality observed is shown in the Figure 5 (a) which was a murky color and has a residual dirt residue from the roof surface of the building. In Figure 5 (b) it showed the color of the water, which is clearer after the first rainwater flows into the first flush diverter channel. This study proved the condition of the water tank is in a clean state without any dirt that subsides in the water storage tank, and is clear enough to be used.

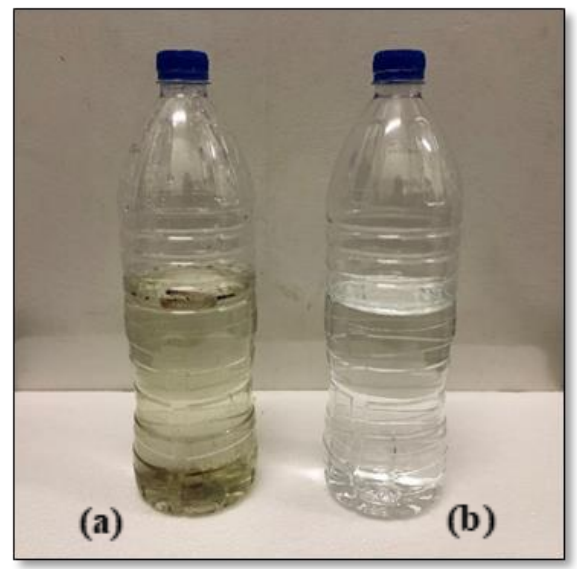

Fig. 5: The differences of rainwater sample: (a) Water in first flush diverter, (b) Water in storage tank.

\section{Conclusion}

This Smart Kit RWH presents in this study consist of water storage tank, existing gutter and main pipe, first flush diverter and some connector pipe to create this complete system. This product is limited to store untreated rain water quality. The rainwater collected therefore, can be used as water storage for household and sanitary equipment- such as flushing cistern and other potable water usage. Thus, this contributes to the good and the benefits of individuals, communities and nations. This product is recommended to help the rural population in particular of having problems in getting clean water.

\section{Acknowledgement}

The authors gratefully acknowledge the supports of the UTHM in supporting the installation of rainwater storage system at the Pagoh UTHM residential college.

\section{References}

[1] Erin Ling and Brian Benham (2014), Virginia cooperative extension Rainwater Harvesting Systems. Journal of Rainwater Harvesting Systems.

[2] Che-Ani AI, Shaari NA. Sairi, MFM Zain \& Tahir MM (2009), Rainwater Harvesting as an Alternative Water Supply in the Future. European Journal of Scientific Research.
[3] NAHRIM (1999), Rainwater guideline for installing a rainwater collection and utilization system. Ministry of housing and local government, Malaysia.

[4] Kassim AHM \& Sunar NM (2004), Review of Utilizing Rainwater for Non-Potable Domestic Uses. National Postgraduate Colloquium School of Chemical Engineering, USM.

[5] Mohd. Shawahid HO, Suhaimi AR, Rasyikah MK, Jamaluddin SA, Huang YF \& Farah MS (2007), Policies and incentives for rainwater harvesting in Malaysia. Rainwater Utilization Colloquium on 19 \& 20 April 2007 at NAHRIM Mini Auditorium.

[6] The Gulf Islands Rainwater Connection Ltd (2018) Retrieved link: www.rainwaterconnection.com/. Date of access: 1 March 2018.

[7] Rain Harvesting Pty Ltd (2015) Retrieved link: https://rainharvesting.com.au/about-us/: 1 March 2018.

[8] World Weather and Climate Information, Weather in Muar (2018). Retrieved from https://weather-and-climate.com/muar-johor-myApril-averages. Access date: May 6, 2018

[9] Lee KE, Mokhtar M, Hanafiah MM, Halim AA \& Badusah J (2016), Rainwater Harvesting as an Alternative Water Resource in Malaysia: Potential, Policies and Development. Journal of cleaner production.

[10] Sunar NM (2006), Kajian Terhadap Kualiti Air Bagi Sistem Pengumpulan Air Hujan Menggunakan Penapis Biopasir. Kolej Universiti Teknologi Tun Hussien Onn: Thesis M. Eng.

[11] Cheng KCS (2017), Rainwater Harvesting (RWH) System as an Alternative Water Source for Non-Potable Use. Faculty of Civil and Environmental Engineering Universiti Tun Hussein Onn Malaysia: Thesis B. Eng.

[12] Yahaya H (2011), A Study On Maintenance of Rainwater Harvesting $(R W H)$ In Malaysia. Department of Building Surveying Faculty of Built Environment University Malaya, Kuala Lumpur: Thesis B. Eng.

[13] Gani P, Sunar NM, Matias-Peralta HM, Ab Aziz AL, Kamaludin NS, Parjo UK, Emparan Q \& Er CM (2015), Experimental study for phycoremediation of Botryococcus sp. on greywater. Applied Mechanics and Materials, vol. 773, pp. 1312-1317.

[14] Paran G, Sunar NM, Matias-Peralta HM, Ab Aziz AL \& Razak ARA (2016), Influence of initial cell concentrations on the growth rate and biomass productivity of microalgae in domestic wastewater. Appl. Ecol. Environ. Res 14, no. 2: 399-409.

[15] Gani, P, Sunar NM, Matias Peralta HM, Ab Aziz AL, Parjo UK \& Rafiq A (2015), Phycoremediation of wastewaters and potential hydrocarbon from microalgae: a review. Advances in Environmental Biology, 9(20), 1-8.

[16] Gani P, Sunar NM, Matias-Peralta HM \& Jamaian SS (2016), Effects of different culture conditions on the phycoremediation efficiency of domestic wastewater. Journal of Environmental Chemical Engineering, 4(4), 4744-4753. 